УДК 551.311 .231

\title{
ПЕТРОХИМИЧЕСКАЯ ХАРАКТЕРИСТИКА КОР ВЫВЕТРИВАНИЯ ОЛЬХОВСКО-ЧИБИЖЕКСКОГО РАЙОНА
}

\section{Мартыненко Ирина Владимировна',} martynenko@tpu.ru

\author{
Ворошилов Валерий Гаврилович', \\ v_g_v@tpu.ru
}

Тимкин Тимофей Васильевич', timkin@tpu.ru

\author{
Мансур Зиаии', \\ m.ziaii47@gmail.com \\ 1 Национальный исследовательский Томский политехнический университет, \\ Россия, 634050, г. Томск, пр. Ленина, 30. \\ 2 Шахрудский технологический университет, \\ Иран, Шахруд.
}

Актуальность исследования обусловлена необходимостью расширения и укрупнения минерально-сырьевого потенциала зо-
лотодобывающей промышленности.
Целью исследования является получение новой дополнительной информации о строении, зональности, минеральном составе
кор выветривания Ольховско-Чибижекского района, а также выявление петрохимических критериев, определяющих условия
повышенных концентраций золота в продуктах гипергенеза. Объекты: остаточные и переотложенные коры выветривания каолинового и гидрорслюдисто-каолинового состава ОльховскоЧибижекского района (Восточный Саян). По условиям залегания, в пределах района выделяются линейные и линейно-площадные типы кор выветривания, преимущественно золотоносные.

Методы. Количественное определение основных породообразующих элементов по профилю коры выветривания проводилось методом рентгенофлюорисцентного анализа при помощи энергодисперсионного рентгенофлуоресцентного микроскопа (ЭДРФ, модель HORIBA XGT-7200). Для характеристики процесса корообразования и количественной его оценки были использованы коэффициенты выветривания. Был проведен анализ распределения породообразующих элементов по профилю коры выветривания с выделением потенциально золотоносного горизонта.

Результаты. В пределах Ольховско-Чибижекского района коры выветривания развиты довольно широко. Среди них выделяются остаточные и переотложенные. Остаточные коры выветривания мел-палеогенового возраста на изучаемой площади района развиты по кислым и средним породам ольховского комплекса, а также карбонатным образованиям чибижекской свиты; представлены они линейным и линейно-площадным морфологическими типами; продукты выветривания сложены глинистым, песчано-глинистым и дресвяно-щебнистым материалом, с преобладанием тонкодисперсной глинистой фракции; эти отложения в значительной степени лимонитизированы и карбонатизированы; по составу остаточные коры выветривания относятся к каолиновому и каолинит-гидрослюдистому типу. Установлено, что остаточные коры выветривания характеризуются развитием полного профиля, в составе которого выделяются зоны: дресвяно-щебенистая, монтмориллонит-гидрослюдистая и охристо-каолиновая. В результате проведенных исследований изучены особенности минерального состава остаточных коры выветривания Ольховско-Чибижекского района; дана минералого-петрохимическая характеристика изучаемых кор выветривания, установлен характер изменения коэффициентов выветривания и особенности распределения золота в вертикальном разрезе кор выветривания, определены геохимические критерии накопления золота в продуктах коры выветривания. Установлено, что повышенные содержания золота приурочены к нижней части верхней охристо-каолиновой зоны с высокими значениями коэффициента ферритизации, аллитизации и коэффициента окисления и минимальными значениями коэффициента выщелачивания. И наоборот, низкие содержания золота характерны для менее выветрелых пород с минимальными значениями коэффициентов ферритизации, аллитизации и окисления.

\section{Ключевые слова:}

Кора выветривания, Восточный Саян, строение, зональность, минералого-геохимические особенности, месторождения золота.

\section{Введение}

В последнее время все больший интерес вызывают месторождения полезных ископаемых, связанные с формацией кор выветривания. Это обусловлено близповерхностным залеганием, высокой степенью дифференциации вещества, что способствует формированию промышленных концентраций целого ряда элементов.
Особое внимание уделяется золотоносным корам выветривания, которые представляют собой значительный сырьевой потенциал для развития золотодобывающей промышленности. Повышенный интерес горнорудных компаний к этим объектам определяется рядом причин:

- возможностью открытой разработки месторождения без применения буровзрывных работ; 
- отсутствием необходимости дробления руды, что значительно удешевляет ее переработку;

- простая технология извлечения золота;

- высокой экономической эффективностью извлечения золота при низких его содержаниях.

Целью данных исследований является получение информации о минералогическом составе и геохимической характеристике кор выветривания Ольховско-Чибижекского района и потенциальной золотоносности изучаемых объектов.

\section{Геологическое строение района}

Золото является одним из ведущих полезных ископаемых Восточного Саяна, а Ольховско-Чибижекский золоторудный район является одним из старейших центров золотодобычи в Сибири.
Ольховско-Чибижекский рудный район занимает северо-западную окраину Восточного Саяна и располагается в пределах Кизир-Казырской структурно-формационной зоны Восточного Саяна, которая на северо-востоке имеет тектонический контакт с байкалидами Дербинской структурно-формационной зоны, на западе ограничивается Минусинским межгорным прогибом девонского возраста, а на юго-западе через Кандатский глубинный разлом граничит со структурами Западного Саяна. Для него характерен двухъярусный геологический разрез: нижний ярус представлен нижнекембрийскими карбонатными, а верхний вулканогенными толщами, прорванными интрузивными образованиями Ольховского габбро-диорит-гранодиоритового и Беллыкского гранитоид-

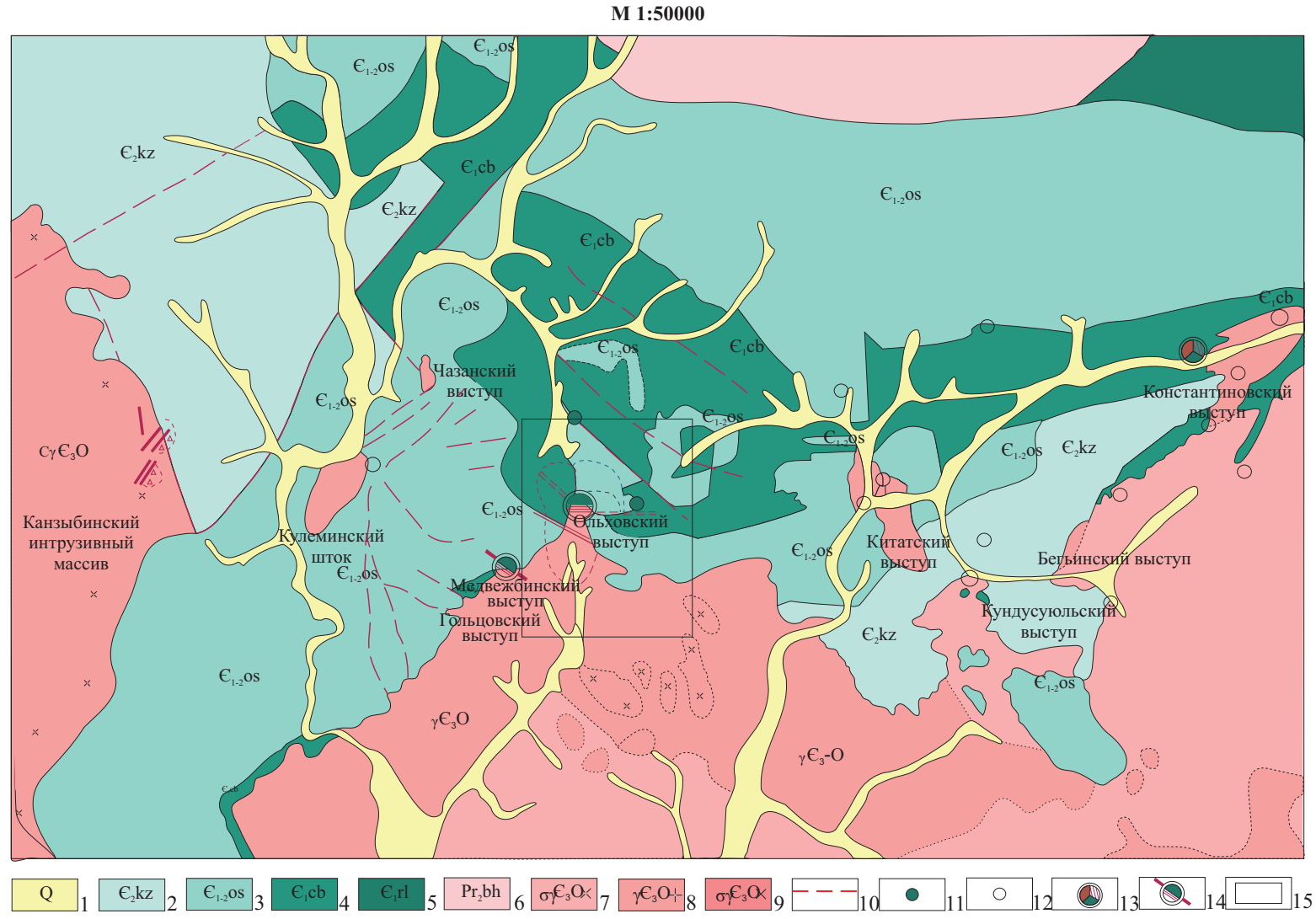

Рис. 1. Геологическая карта северной части Ольховско-Чибижекского рудного района: 1) современные аллювиальные отложения, глины сугленки, пески; 2) кизирская свита. Риолиты, туфы, линзы известняков; 3) осиновская свита. Аргиллиты, алевролиты, туфы кислого и среднего состава, туфопесчаники; 4) чибижекская свита. Известняки, прослои и линзы аргиллитов и туфов; 5) колпинская свита. Песчаники, алевролиты, сланцы; 6) кварц-хлоритовые, кварц-эпидот-хлоритовые сланцы; 7) диориты; 8) граниты; 9) гранодиориты, плагиограниты; 10) тектонические нарушения; 11) коренные месторождения золота, сульфидные залежи; 12) рудопроявления золота; 13) месторождения золота, жилы кварц-карбонатные с сульфидами и гематитом; 14) месторождения золота, жилы кварц-сульфидного состава; 15) контур участка работ

Fig. 1. Geological map of the Northern part of Olkhov-Chibizhek ore district: 1) modern alluvial deposits, clay, loam, sand; 2) Kizir suite. Rhyolites, tuffs, limestone lenses; 3) Osinovsk suite. Argillites, siltstones, felsic and intermediate tuffs, tuff-sandstones; 4) Chibizhek suite. Limestone, interlayers and lenses of mudstone and tuff; 5) Kolpino suite. Sandstones, siltstones, slates; 6) quartzchlorite, quartz-epidote-chlorite shales; 7) diorites; 8) granites; 9) granodiorites, plagiogranites; 10) tectonic disturbances; 11) primary gold deposits, sulphide shoot; 12) gold-ore occurrence; 13) gold deposits, quartz-carbonate veins with sulphides and hematite; 14) gold deposits, quartz-carbonate veins; 15) site of work 
ного комплексов, которые образуют крупные и удлиненные в плане батолитовые массивы (рис. 1) [1].

Главной геотектонической структурой района является Артемовская мегантиклиналь, которая простирается в северо-западном направлении на 120 км. В строении мегантиклинали принимают участие в восточной части верхнепротерозойские метаморфические сланцы кувайской серии и существенно карбонатные отложения овсиниковской свиты. В западной части развиты кембрийские вулканогенно-осадочные образования колпинской (песчано-сланцевые нижнекембрийские), балахтисонской или чибижекской (конгломераты, известняки, доломиты), осиновской (туфогенные породы) и кизирской (вулканические породы) свит [2]

\section{Особенности коры выветривания}

На всей территории Восточного Саяна рыхлые отложения, к которым приурочены древние россыпи, представлены: а) образованиями древней коры выветривания на коренных породах и на древних аллювиальных и делювиальных отложениях; б) переотложенными продуктами коры выветривания; в) аллювиально-делювиальными отложениями древних долин, не затронутыми химическим выветриванием [2, 3]. Первичное оруденение представлено метасоматически измененными сульфидными залежами и умеренно-сульфидными маломощными кварцевыми телами жильного и штокверкового типов, которые локализуются главным образом в гранитоидах. Умеренно-сульфидные кварцевые жилы имеют сравнительно небольшое распространение. Минеральный состав первичного оруденения: кварц, карбонаты, пирит, в незначительном количестве пирротин, золото [4].

На изучаемой площади довольно широко развиты рыхлые отложения меловой, палеогеновой, неогеновой и четвертичной систем. При этом образования палеоген-неогенового возраста в большинстве сохранились в пределах молодых впадин, а также на обрывках террас высоких уровней (выше 50 м). К образованиям верхнемелового возраста с некоторой условностью относятся дресвяно-щебеночно-глинистые осадки, сохранившие структуру материнских пород, являющиеся субстратом палеогеновых отложений. Мощность рыхлых образований не постоянна и меняется в зависимости от типа рельефа. На большей части площади района мощность рыхлого покрова не превышает $5 \ldots 10$ м, но на отдельных участках достигает 100 и более метров [5].

Остаточные коры выветривания мел-палеогенового возраста на изучаемой площади района пользуются широким распространением, развиты по кислым породам ольховского комплекса и карбонатным образованиям чибижекской свиты. Наиболее развиты коры выветривания каолинового и гидрослюдисто-каолинового состава [6]. По условиям залегания, в пределах района выделяются линейная и линейно-площадная коры, с преобладанием кор выветривания линейного типа. Продукты выветривания сложены глинистым и песчано-глинистым материалом. Эти отложения в значительной степени лимонитизированы и карбонатизированы, местами в них присутствуют железистые и железо-марганцевые конкреции [7].

Остаточная кора выветривания, сформированная на гранитах и гранодиоритах, традиционно характеризуется развитием полного профиля выветривания [8], в составе которого выделяются три основные зоны (снизу вверх):

1) дресвяно-щебенистая;

2) монтмориллонит-гидрослюдистая с каолиниTOM;

3) каолиновая с охристыми включениями гидроокислов железа и марганца.

Отличительной особенностью коры выветривания является преобладание минералов тонкодисперсной, глинистой фракции [9].

\section{Методика исследования}

С целью геохимической характеристики выделенных зон было проведено количественное определение основных породообразующих элементов по профилю коры выветривания методом рентгенофлюоресцентного анализа (РФА). РФА как метод реализации силикатного анализа выполнялся с использованием микроанализатора HORIBA X-Ray Analytical Microscope XGT 7200, оснащенного энергодисперсионным детектором с пределом обнаружения химических элементов до 0,01\%. Данный прибор позволяет делать качественный и количественный химический анализ в диапазоне измерения элементов от натрия до урана, а также анализировать распределения элементов с использованием функции картирования. Анализ производился на подготовленных препаратах (таблетках) при параметрах: напряжение 50 кВ, сила тока 0,5 мА, время сканирования 100 с, площадь сканирующего луча 1,2 мм. Таблетки изготавливались следующим образом: истертая проба спрессовывалась под гидравлическим прессом, после чего спекалась в муфельной печи в течение 9 часов при температуре $900{ }^{\circ} \mathrm{C}$. Пробы были отобраны из керна скважин с интервалом опробования $1 \mathrm{~m}$. Всего было исследовано 48 образцов, по три измерения на пробу.

Для характеристики процесса корообразования и количественной их оценки были применены следующие параметры, предложенные Е.В. Скляровым (2001 г.) и И.И. Гинзбургом (1963 г.), с дополнениями автора:

1) индекс выветривания $[10,11]$;

2) коэффициент ферритизации;

3) коэффициент окисления;

4) коэффициент аллитизации;

5) коэффициент выщелачивания;

6) коэффициент разложения [12].

Индекс химического изленения (CIA - Chemical Index of alteration). Критерием для разграни- 
чения отложений принято считать значение индекса, равное 70. Невыветрелые породы характеризуются значениями СIA порядка 50, тогда как сильно выветрелые разновидности соответствуют СІА около 100.

$$
\left[\mathrm{Al}_{2} \mathrm{O}_{3} /\left(\mathrm{Al}_{2} \mathrm{O}_{3}+\mathrm{CaO}+\mathrm{Na}_{2} \mathrm{O}+\mathrm{K}_{2} \mathrm{O}\right)\right] * 100[10,11,13] \text {. }
$$

Коры выветривания, развитые по гранитам, характеризуются постепенным увеличением индекса химического выветривания снизу вверх, от слабо выветрелых исходных пород с индексом CIA 55 до интенсивно преобразованных пород с индексом CIA до 80.

Коэффициент ферритизации - отношение содержаний окиси железа к кремнезему в продуктах выветривания к такому же отношению в материнской породе:

$$
\left(\mathrm{Fe}_{2} \mathrm{O}_{3} / \mathrm{SiO}_{2}\right) /\left(\mathrm{Fe}_{2} \mathrm{O}_{3} / \mathrm{SiO}_{2}\right) \text { исх. }
$$

Коэффициент ферритизации колеблется по профилю выветривания от 0,6 до 2,5, достигая максимальных значений в верхней части сформированной коры выветривания.

Коэффициент окисления - отношение суммы содержаний окиси железа, двуокиси марганца в продуктах выветривания к такой же сумме окиси и закиси железа и закиси марганца в материнской породе:

$$
\left(\mathrm{Fe}_{2} \mathrm{O}_{3}+\mathrm{MnO}_{2}\right) /\left(\mathrm{Fe}_{2} \mathrm{O}_{3}+\mathrm{FeO}+\mathrm{MnO}\right) \text { исх. }
$$

Значения коэффициента окисления находятся в пределах от 0,65 в зоне слабо выветрелых пород, которые представлены гранитом, гранодиоритом и обломкками кварц-альбит-хлорит-серицитовых, кварц-альбит-эпидот-хлоритовых, кварц-мусковитовых и кварц-амфиболитовых метасоматитов, и продуктами их разложения, и до 2,5 в охристокаолиновой зоне.

Коэффициент аллитизации - отношение содержаний глинозема к кремнезему в продуктах выветривания к такому же отношению в материнской породе:

$$
\left(\mathrm{Al}_{2} \mathrm{O} 3 / \mathrm{SiO}_{2}\right) /\left(\mathrm{Al}_{2} \mathrm{O}_{3} / \mathrm{SiO}_{2}\right) \text { исх. }
$$

Коэффициент аллитизации находится в интервале от 0,65 до 1,12 .

Коэффициент выщелачивания показывает степень выноса оснований в продуктах выветривания по отношению к материнской породе:

$\left(\mathrm{CaO}+\mathrm{K}_{2} \mathrm{O}+\mathrm{Na}_{2} \mathrm{O}\right) /\left(\mathrm{CaO}+\mathrm{K}_{2} \mathrm{O}+\mathrm{Na}_{2} \mathrm{O}\right)$ исх.

Значение коэффициента выщелачивания колеблется в пределах от 0,1 до 1,7.

Коэффициент разложения - отношение содержания оксида трехвалентного железа к содержанию оксида кальция в материнской породе.

$$
\mathrm{Fe}_{2} \mathrm{O}_{3} / \mathrm{CaO} \text { исх [12]. }
$$

Разброс в значениях коэффициента разложения весьма значительный. Минимальные значения характерны для слабо выветрелых пород и составляют 0,08, а максимальные фиксируются в верхней части профиля коры и имеют значение 25,67, что и отражает процесс корообразования с полным профилем выветривания [14].

\section{Результаты исследований и обсуждение результатов}

Охристо-каолиновая зона - верхняя интенсивно проработанная зона сформированной коры выветривания. В минералогическом отношении характеризуется преобладанием пелитовой фракции крупности, которая состоит из кальцита, кварца, каолинита, разупорядоченного смектита, плагиоклаза, калиевого полевого шпата, иллита, гематита и гетитачто согласуется с выводами E. Galan c соавторами и Georges Martial Ndzana, Li Huang и др. $[15,16]$. Песчаная и алевролитовая фракции представлены следующими минералами: тяжелая фракиия - магнетит, мартит и мушкетовит, гематит, гидроокислы желез, амфиболы (роговая обманка, актинолит), циркон (гиацинт), золото, ед. знаки - ильменит, пирит и псевдоморфозы лимонита по пириту, марганцевые минералы, хлоритоид, шпинель, корунд, рутил, анатаз, легкая фракиия - обломки обохренного кварца, серицитизированный плагиоклаз, калиевые полевые шпаты, карбонаты. Дресвяная фракция (более 1 мм) - крупные обохренные обломки кварца, гематита, реже обломки интенсивно выветрелых материнских пород - гранитов, кварц-альбит-хлорит-серицитовых, кварц-альбит-хлоритовых и кварц-мусковитовых метасоматитов.

Выделенная охристо-каолиновая зона характеризуется следующими петрохимическими параметрами, рассчитанными по предложенной методике: коэффициент ферритизации от 2,2 до 2,46; коэффициент окисления 1,7-2,27, коэффициент аллитизации $0,71-0,94$; коэффициент выщелачивания 0,88-1,03 (рис. 2). Коэффициент разложения в этой зоне имеет наибольшие значения от 6,5 до 17,8 , а по отдельным скважинам коэффициент разложения достигает значений до 27. Индекс выветривания, рассчитанный по методике, предложенной Е.В. Скляровым (2001 г.) и Я.В. Юдовичем (2000 г.), характеризуется высокими значениями от 68 до 76. Максимальные концентрации золота, которые достигают значений 4,5 г/т, при среднем значении 2,7 г/т, приурочены к нижней части верхней охристо-каолиновой зоны, что не противоречит выводам Н.А. Рослякова, Ю.А. Калинина и др. [17, 18].

Средняя монтмориллонит-гидрослюдистая зона представлена минералами глинистой фракции - гидромусковитом и вермикулитом, монтмориллонитом и смешаннослойными хлорит-монтмориллонитовыми образованиями. Песчаная и алевролитовая фракции крупности представлены магнетитом, гематитом и гидроокислами железа, часто в виде псевдоморфоз по кубическим и пентагон-додекаэдрическим кристаллам пирита, амфиболами, редко ильменитом и рутилом, в незначительном количестве присутствует хлоритоид, шпинель, корунд, циркон, эпидот, единичные знаки марганцевых минералов, и самородного золота, легкая фракция - кварц, плагиоклазы, полевые шпаты и слюды. Дресвяная фракция крупности 
представлена обломками выветрелых кварц-альбит-хлорит-серицитовых, кварц-альбит-эпидотхлоритовых, кварц-мусковитовых, кварц-амфиболитовых метасоматитов и кварца, который покрыт пленкой гидроокислов железа и марганца, реже гематита.

В петрохимическом отношении выделенная монтмориллонит-гидрослюдистая зона, в отличие от верхней охристо-каолиновой зоны, имеет более низкие коэффициенты: ферритизации от 1,2 до 2,1 ; окисления $0,9-1,53$, аллитизации $0,56-0,7$, разложения 2,7-6,7 и более высокий коэффициент выщелачивания 0,9-1,2 (рис. 2). Индекс химического выветривания составляет $60-68$. Содержания золота в монтмориллонит-гидрослюдистой зоне не превышают 0,5-1 г/т, при среднем 0,43 г/т.

Нижняя зона дезинтеграции сложена обломками кварц-альбит-хлорит-серицитовых, кварц-альбит-эпидот-хлоритовых, кварц-мусковитовых и кварц-амфиболитовых метасоматитов и продуктами их разложения. В незначительном количестве присутствуют минералы песчаной и алевролитовой фракций крупности - кварц, калиевый полевой шпат, серицитизированные плагиоклазы, слюды, магнетит, гематит, гидроокислы железа, в том числе и псевдоморфозы по пириту, амфиболы, циркон, единичные знаки ильменита, рутила, барита, корунда, шпинели. Пелитовая фракция представлена кальцитом, присутствуют кварц, разупорядоченный смектит, иллит, плагиоклаз, калиевый полевой шпат, следы доломита, ангидрита.

Коэффициенты выветривания в выделенной зоне дезинтергации указывают на породы со слабой степенью их гипергенной проработки. Коэффициент ферритизации от 0,4 до 1,02, коэффициент окисления $0,9-1,2$, аллитизации $0,45-0,7$, разложения $1,58-4,3$, коэффициент выщелачивания 1-1,7 (рис. 2). Индекс химического выветривания составляет 58-64. Повышенные содержания золота отмечаются в единичных пробах, до 3,8 г/т при среднем 0,5 г/т. Эти данные не противоречат представлениям К.Р. Ковалева, Е.А. Наумова и др. (2009 г.) и согласуются с выводами Н.В. Петровской $(1973$ г.) [19-21].

Помимо характеристики выделенных зон, с помощью известной методики Гинзбурга [12] нами установлена зависимость между поведением золота в коре выветривания и значениями показателей выветривания. Так, максимальные содержания золота до 4,5 г/т приурочены к верхней охристокаолиновой зоне с высокими значениями коэффициента ферритизации, аллитизации и коэффициента окисления и минимальными значениями коэффициента выщелачивания. И наоборот, низкие содержания золота характерны для менее выветрелых пород с минимальными значениями коэффициентов ферритизации, аллитизации и окисления (рис. 2).

Наряду с остаточной корой на площади рудного района выделяются продукты переотложенной коры выветривания в водных, наземных и озерно-болотных условиях [1]. Это преимущественно светло-коричневые глинистые, глинисто-щебенистые образования, представленные каолинитом и гидрослюдой с обломками гранита, гранодиорита, кварца, известняка и бурого железняка. Песчаная и алевритовая фракции содержат магнетит, гематит, окислы и гидроокислы железа и марганца, пирит. В незначительных количествах присутствует ильменит, рутил, брукит, анатаз, лейкоксен, циркон, корунд и золото. Минералы легкой фракции - кварц, полевые шпаты, редкие знаки марганцевых минералов и карбонатов. Гранулометрический состав продуктов переотложенной коры выветривания следующий: дресвяная фракция $35 \%$, песчаная - $10 \%$, алевролитовая - $7 \%$ и

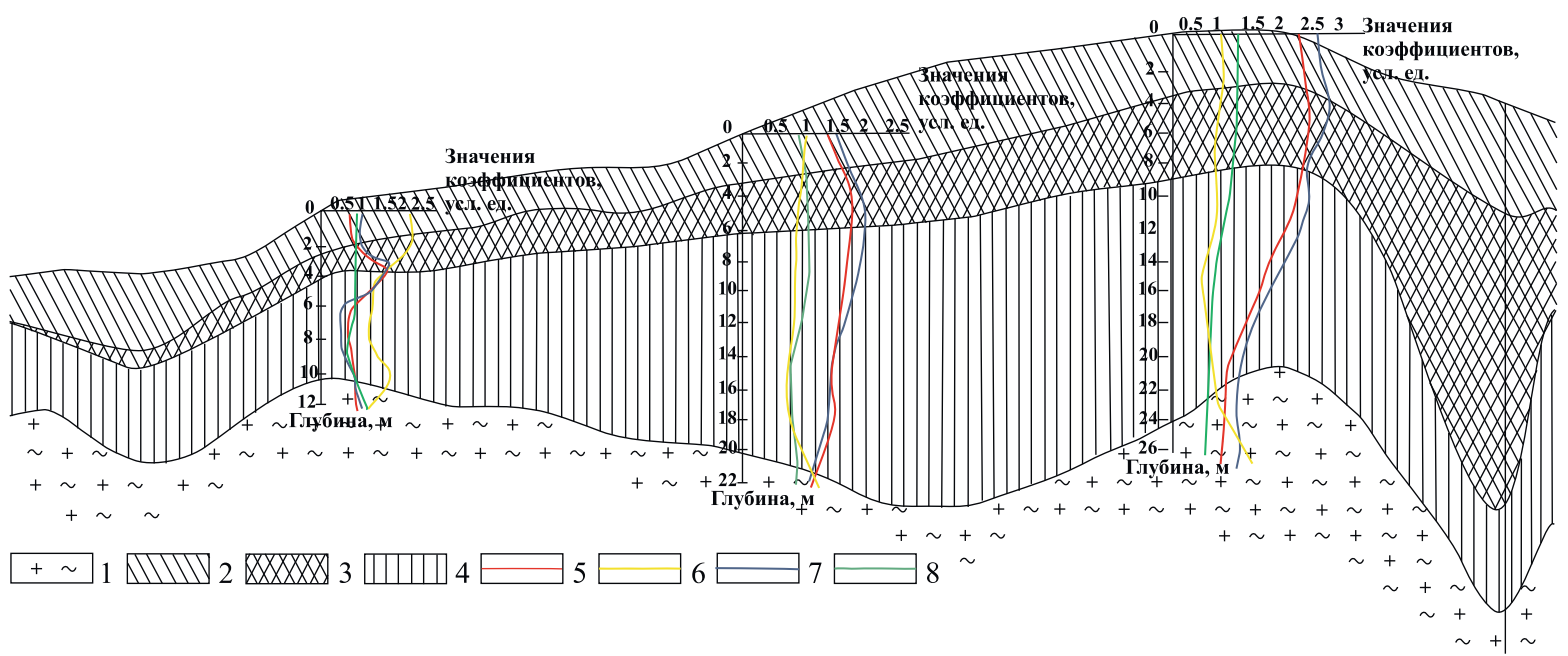

Pис. 2. (хематический геологический разрез. Зоны: 1) дресвяно-щебенистая; 2) охристо-каолиновая; 3) нижняя часть охристокаолиновой зоны с повышенными содержаниями золота; 4) монтмориллонит-гидрослюдистая. Коэффициенты: 5) окисления; 6) выщелачивания; 7) ферритизации; 8) аллитизации

Fig. 2. Schematic geological cross section. Zones: 1) gruss-breakstone; 2) ochre-kaolin; 3) lower part of the ochre-kaolin zone with high gold content; 4) montmorillonite-hydromica. Coefficients: 5) oxidation; 6) leach; 7) ferritization; 8) allitization 
глинистая фракция - 48 \% . Эти образования залегают на элювиальной коре и сохранились в пределах древней поверхности. Мощность от 1 до 10 м, в карстовых полостях до 40 м [9].

\section{Выводы}

1. Установлено, что в пределах Ольховско-Чибижекского района коры выветривания развиты довольно широко. Среди них выделяются остаточные и переотложенные. Остаточные коры выветривания мел-палеогенового возраста на площади района развиты по кислым и средним породам ольховского комплекса, а также карбонатным образованиям чибижекской свиты. Представлены они линейным и линейно-площадным морфологическими типами. Продукты выветривания сложены глинистым, песчано-глинистым и дресвяно-щебнистым материалом, с преобладанием тонкодисперсной глинистой фракции. Эти отложения в значительной степени лимонитизированы и карбонатизированы.

2. По составу остаточные коры выветривания относятся к каолиновому и каолинит-гидрослю-

\section{СПИСОК ЛИТЕРАТУРЫ}

1. Золотоносные коры выветривания Сибири / под ред. С.С. Сердюка. - Красноярск: КНИИГиМС, 2002. - 116 с.

2. Хазагаров А.М. Мезозойские и третичные золотоносные россыпи Восточного Саяна и Кузнецкого Алатау // Геология россыпей / под ред. В.И. Смирнова. - М.: Наука, 1965. C. $188-198$.

3. Цыкин Р.А., Попова Н.Н. Кайнозой северо-западной части Восточного Саяна. - Красноярск: СФУ, 2009. - 115 с.

4. Коробейников А.Ф., Зотов И.А. Комплексные месторождения благородных и редких металлов. - Томск: Изд-во ТПУ, 2006. $327 \mathrm{c.}$

5. Калинин Ю.А., Росляков Н.А., Прудников С.Г. Золотоносные коры выветривания юга Сибири. - Новосибирск: Гео, 2006. $339 \mathrm{c.}$

6. Sidorova E., Sitdikova L., Izotov V. The Major Types of the Weathering Crust of the Eastern Russian Plate and its Mineralogical and Geochemical Features // Procedia Earth and Planetary Science. 2015. - V. 15. - P. 573-578.

7. Мартыненко И.В. Золото в продуктах коры выветривания Ольховского рудного поля // Россыпи и месторождения кор выветривания: современные проблемы исследования и освоения: Матер. XIV Междунар. совещ. - Новосибирск, 2010. C. $426-430$.

8. Alavi Nezhad Khalil Abad S.V. et al. Characteristics of weathering zones of granitic rocks in Malaysia for geotechnical engineering design // Engineering Geology. - 2016. - V. 200. P. 94-103.

9. Мартыненко И.В., Мазуров А.К. Зональность и минералогогеохимический состав продуктов коры выветривания Ольховско-Чибижекского района // Известия Томского политехнического университета. - 2011. - Т. 318. - № 1. - С. 23-28.

10. Интерпретация геохимических данных / Е.В. Скляров, И.Г. Бараш, В.А. Буланов, Д.П. Гладкочуб, Т.В. Донская, А.В. Иванов, Е.Ф. Летникова, А.Г. Миронов, А.И. Сизых. М.: Интермет Инжиниринг, 2001. - 288 с. дистому типу. Установлено, что они характеризуются развитием полного профиля, в составе которого выделяются зоны (снизу вверх): дресвяно-щебенистая, монтмориллонит-гидрослюдистая и охристо-каолиновая. Повышенные содержания золота приурочены к нижней части верхней охристо-каолиновой зоны.

3. Определены геохимические критерии накопления золота в продуктах коры выветривания. Установлен характер изменения коэффициентов выветривания и особенности распределения золота в вертикальном разрезе кор выветривания. Максимальные содержания золота до 4,5 г/т приурочены к верхней охристо-каолиновой зоне с высокими значениями коэффициента ферритизации, аллитизации и коэффициента окисления и минимальными значениями коэффициента выщелачивания. И наоборот, низкие содержания золота характерны для слабо выветрелых пород с минимальными значениями коэффициентов ферритизации, аллитизации и окисления.

Работа выполнена при финансовой поддержке гранта РФФИ № 18-45-700019.

11. Jiang-Hai Yang, Yuan-Sheng Du. Weathering geochemistry and palaeoclimate implication of the Early Permian mudstones from eastern Henan Province, North China // Journal of Palaeogeography. - 2017. - V. 6. - № 4. - P. 370-380.

12. Гинзбург И.И. Термины и понятия относящиеся к коре выветривания / / Обзор геологических понятий и терминов в применении к металлогении. - М.: АН СССР, 1963. - С. 151-158.

13. Юдович Я.Э., Кетрис М.П. Основы литохимии. - СПб.: «Наука» РAH, 2000. - $480 \mathrm{c}$.

14. Geological and geochemical characteristics in the paleo-weathering crust sedimentary type REE deposits, western Guizhou, China / Lingjie Zhou, Zhengwei Zhang, Yujiao Li et al. // Journal of Asian Earth Sciences. - 2013. - V. 73. - P. 184-198.

15. Galan E., Ferrell R.E. Genesis of Clay Minerals // Developments in Clay Science. Ch. 3. - 2013. - V. 5. - P. 83-126.

16. Characteristics of clay minerals in soil particles from an argillic horizon of Alfisol in central China / G.M. Ndzana, L. Huang, J.B. Wang, Z.Y. Zhang // Applied Clay Science. - January 2018. - V 151. - P. 148-156.

17. Росляков Н.А. Геохимия золота в зоне гипергенеза. - Новосибирск: Наука, 1981. - 239 с.

18. Gold in the Weathering Crust at the Suzdal' deposit (Kazakhstan) / Yu.A. Kalinin, K.R. Kovalev, E.A. Naumov, M.V. Kirillov // Russian Geology and Geophysics. - March 2009. - V. 50. P. $174-187$.

19. Петровская Н.В. Самородное золото. - М.: Наука, 1973. $349 \mathrm{c.}$

20. Climatic zonation and weathering control on sediment composition (Angola) / P. Dinisa, E. Garzantib, P. Vermeeschc, J. Huvid // Chemical Geology. - 2017. - V. 467. - P. 110-121.

21. Kovalev K.R. et al. Relationship of antimony with gold mineralization in the ore districts of Eastern Kazakhstan // Russian Geology and Geophysics. - 2014. - V. 55. - P. 1170-1182.

Поступила 22.09.2018 г. 


\section{Информация об авторах}

Мартыненко И.В., ассистент отделения геологии Инженерной школы природных ресурсов Национального исследовательского Томского политехнического университета.

Ворошилов В.Г., доктор геолого-минералогических наук, профессор отделения геологии Инженерной школы природных ресурсов Национального исследовательского Томского политехнического университета.

Tuлкин T.B., кандидат геолого-минералогических наук, доцент отделения геологии Инженерной школы природных ресурсов Национального исследовательского Томского политехнического университета.

Зиаии М., кандидат геолого-минералогических наук, доцент Шахрудского технологического университета. 


\title{
PETROCHEMICAL CHARACTERIZATION OF WEATHERING CRUSTS OF OLKHOVSK-CHIBIZHEK DISTRICT
}

Irina V. Martynenko',

martynenko@tpu.ru

\author{
Valery G. Voroshilov', \\ v_g_v@tpu.ru \\ Timofey V. Timkin', \\ timkin@tpu.ru
}

\author{
Mansour Ziaii ${ }^{2}$, \\ m.ziaii47@gmail.com \\ ${ }^{1}$ National Research Tomsk Polytechnic University, \\ 30, Lenin Avenue, Tomsk, 634050, Russia. \\ 2 Shahrood University of Technology, \\ Bolvar Daneshka, Shahrood, 3619995161, Iran.
}

The relevance of the research is defined by the need to expand and strengthen the resource potential of the gold mining industry. The aim of the study is to obtain new information about the structure, zonality, mineral composition of weathering crusts of OlkhovskChibizhek district and to define the geochemical criteria that contribute to concentration of gold mineralization.

Objects: residual and redeposited weathering crust of kaolinite and hydromica-kaolin composition from Olkhovsk-Chibizhek area (East Sayan). According to the occurrence, there are linear and linearly areal types of weathering crusts, mainly gold-bearing, within the area. Research methods include quantitative determination of the main rock-forming elements of the weathering crust by $X$-ray fluorescence analysis using energy dispersive $x$-ray fluorescence microscope (HORIBA XGT-7200). The weathering coefficients were used to characterize weathering crust formation and its quantitative evaluation. The analysis of the rock-forming elements distribution across the weathering crust with potential gold-bearing horizon determination was performed.

Research results. It was found that the residual and redeposited weathering crusts are widely spread within Olkhov-Chibizhek district. The residual weathering crusts of the Cretaceous-Paleogene age are developed on felsic and intermediate rocks of the Olkhovsk complex and on carbonate formation of the Chibizhek suite. They are represented by linear and linear-areal morphological types. The weathering products are composed of clay, sand-clay and gruss-gravel material, with a predominance of fine-dispersed clay fraction. They are intensely limonitized and carbonized. Composition of the residual weathering crust belongs to the kaolinite and kaolinite-hydromice type. Weathering crust profile is characterized by the development of a complete profile, which has gruss-detrital, montmorillonite-hydromica and ochre-kaolin zone. As a result, the mineral composition peculiarities of the weathering crust of Olkhov-Chibizhek district are studied; mineralogical and petrochemical features of residual weathering crust are characterized. The nature of the weathering ratios change and characteristics of gold distribution across a vertical section are established. Geochemical criteria for gold accumulation in the products of the weathering crust are defined. High contents of gold are confined to the lower part of the upper ochre-kaolin zone with high values of the ferritization, allitization and oxidation coefficients, and minimum values of the leaching coefficient. Conversely, low content of gold is typical for less weathered rocks with low values of ferritization, allitization and oxidation coefficients.

\section{Key words:}

Weathering crust, Eastern Sayan, structure, zonation, mineralogical and geochemical features, gold deposits.

The research was financially supported by the RFBR grant no. 18-45-700019.

\section{REFERENCES}

1. Zolotonosnye kory vyvetrivaniya Sibiri [Au-bearing weathering crusts of Siberia]. Ed. by S.S. Serdyuk. Krasnoyarsk, KNIIGiMS Publ., 2002.116 p.

2. Khazagarov A.M. Mezozoyskie i tretichnye zolotonosnye rossypi Vostochnogo Sayana i Kuznetskogo Alatau [Mesozoic and tertiary gold-bearing placers of East Sayan and Kuznetsk Alatau]. Geologiya rossypey. Ed. by V.I. Smirnov. Moscow, Nauka Publ., 1965. pp. 188-198.

3. Tsykin R.A., Popova N.N. Kaynozoy severo-zapadnoy chasti Vostochnogo Sayana [The Cenozoic of the North-Western part of Eastern Sayan]. Krasnoyarsk, SFU Publ., 2009. 115 p.

4. Korobeynikov A.F., Zotov I.A. Kompleksnye mestorozhdeniya blagorodnykh i redkikh metallov [Complex deposits of precious and rare metals]. Tomsk, TPU Publ. house, 2006. 327 p.
5. Kalinin Yu.A., Roslyakov N.A., Prudnikov S.G. Zolotonosnye kory vyvetrivaniya yuga Sibiri [Au-bearing weathering crusts of the South Siberia]. Novosibirsk, Geo Publ., 2006. 339 p.

6. Sidorova E., Sitdikova L., Izotov V. The Major Types of the Weathering Crust of the Eastern Russian Plate and its Mineralogical and Geochemical Features. Procedia Earth and Planetary Science, 2015, vol. 15. pp. 573-578.

7. Martynenko I.V. Zoloto v produktakh kory vyvetrivaniya Olkhovskogo rudnogo polya [Gold in the weathering crust products of Olkhovsk ore field]. Rossypi i mestorozhdeniya kor vyvetrivaniya: sovremennye problemy issledovaniya i osvoeniya. Materialy XIV Mezhdunarodnogo soveshchaniya [Deposits of weathering crusts: modern problems of studying and exploration. Proc. of the XIV International meeting]. Novosibirsk, 2010. pp. $426-430$. 
8. Alavi Nezhad Khalil Abad S.V. Characteristics of weathering zones of granitic rocks in Malaysia for geotechnical engineering design. Engineering Geology, 2016, vol. 200, pp. 94-103.

9. Martynenko I.V., Mazurov A.K. Zoning and mineralogical-geochemical composition of the weathering crust products of Olkhovsk-Chibizhek district. Bulletin of the Tomsk Polytechnic University, 2011, vol. 318, no. 1, pp. 23-28. In Rus.

10. Sklyarov E.V., Barash I.G., Bulanov V.A., Gladkochub D.P., Donskaya T.V., Ivanov A.V., Letnikova E.F., Mironov A.G., Sizykh A.I. Interpretatsiya geokhimicheskikh dannykh [Interpretation of geochemical data]. Moscow, Intermet Inzhiniring Publ., 2001. $288 \mathrm{p}$

11. Jiang-Hai Yang, Yuan-Sheng Du. Weathering geochemistry and palaeoclimate implication of the Early Permian mudstones from eastern Henan Province, North China. Journal of Palaeogeography, 2017, vol. 6, no. 4, pp. 370-380.

12. Ginzburg I.I. Terminy i ponyatiya otnosyashchiesya $k$ kore vyvetrivaniya [Terms and concepts related to weathering crust]. Obzor geologicheskikh ponyatiy $i$ terminov $v$ primenenii $k$ metallogenii [Review of geological terms related to metallogenie]. Moscow, AN SSSR Publ., 1963. pp. 151-158.

13. Yudovich Ya.E., Ketris M.P. Osnovy litokhimii [Basics of lithochemistry]. St-Petersburg, Nauka RAN Publ., 2000. 480 p.

14. Lingjie Zhou, Zhengwei Zhang, Yujiao Li et al. Geological and geochemical characteristics in the paleo-weathering crust sedimen- tary type REE deposits, western Guizhou, China. Journal of Asian Earth Sciences, 2013, vol. 73, pp. 184-198

15. Galan E., Ferrell R.E. Genesis of Clay Minerals. Developments in Clay Science. Ch 3. 2013, vol. 5, pp. 83-126.

16. Ndzana G.M., Li Huang, Jin Bo Wang, Zhi Yi Zhang. Characteristics of clay minerals in soil particles from an argillic horizon of Alfisol in central China. Applied Clay Science, January 2018, vol. 151, pp. 148-156.

17. Roslyakov N.A. Geokhimiya zolota $v$ zone gipergeneza [Gold geochemistry in hypergenesis]. Novosibirsk, Nauka Publ., 1981. $239 \mathrm{p}$.

18. Kalinin Yu.A., Kovalev K.R., Naumov E.A., Kirillov M.V. Gold in the Weathering Crust at the Suzdal deposit (Kazakhstan). Russian Geology and Geophysics, March 2009, pp. 174-187.

19. Petrovskaya N.V. Samorodnoe zoloto [Native gold]. Moscow, Nauka Publ., 1973. 349 p.

20. Dinisa P., Garzantib E., Vermeeschc P., Huvid J. Climatic zonation and weathering control on sediment composition (Angola). Chemical Geology, 2017, vol. 467, pp. 110-121.

21. Kovalev K.R. Relationship of antimony with gold mineralization in the ore districts of Eastern Kazakhstan. Russian Geology and Geophysics, 2014, vol. 55, pp. 1170-1182.

Received: 22 September 2018.

\section{Information about the authors}

Irina V. Martynenko, assistant, National Research Tomsk Polytechnic University.

Valery G. Voroshilov, Dr. Sc., professor, National Research Tomsk Polytechnic University.

Timofey V. Timkin, Cand. Sc., associate professor, National Research Tomsk Polytechnic University.

Mansour Ziaii, PhD, associate professor, Shahrood University of Technology. 